\title{
Russo-Ukrainian Gas War: The Lack of a Common Strategy Jeopardizes European Unity
}

\author{
Michele Pigliucci \\ Department of History, University of Rome “Tor Vergata”, Italy
}

Copyright $\bigcirc 2016$ by authors, all rights reserved. Authors agree that this article remains permanently open access under the terms of the Creative Commons Attribution License 4.0 International License

\begin{abstract}
Despite low attention level in Western media, Ukrainian crisis is not just a local issue, and it is going to jeopardize European integration process due to geopolitical key position of Ukraine in natural gas delivery system. In facts, besides military race, carrying real dangers, a parallel gas war is staging in Ukraine, where U.S.A. - new hydrocarbon exporter thanks to "shale revolution" - is trying to break the Russian monopoly on Europe, by opening new energetic supply routes, in order to prevent Russia to use this strategic tool to control Europe countries. However, the low price of oil barrel is going to jeopardize U.S.A. plans. In the meantime, Ukraine is close to default due to debt crisis. The decrease of domestic production of energy - caused by political and geopolitical reason related to civil war and annexation of Crimea to Russia - worsens the crisis and prevent Ukraine to free from energetic dependence from Russia, a Moscow's tool to influence internal situation. Russia is trying to overcome Ukrainian bottleneck by opening new routes for Europe, in order to keep monopoly in energetic European marketplace avoiding access of U.S.A. shale gas. In this scenario, the main problem for Europe is the lack of a common strategy: divided in Russian-friendly countries, anti-Russian and "lone wolves", European countries pursue their own energetic policies, weakening European Union and threating to bring Europe to a new division in spheres of influence.
\end{abstract}

Keywords Geopolitics, Gas, Ukraine, Russia, Europe, Energy

\section{Introduction}

Starting from President Yanukovych's decision not to sign the agreement between Ukraine and the EU, leading to heavy clashes and following deposition of the President, the tension in Ukraine has grown quickly and flown in a violent civil war, involving Ukrainian troops leaded by new president Poroshenko on one side, and Russian-backed separatist militias of the Eastern regions on the other side.
Far from being a local issue, the Ukrainian crisis is going to represents one of the most risky geopolitical issues involving Europe, despite the low visibility level on western media [1]. In fact, the Ukrainian geopolitical position is a key issue in European balance of power: expansion of N.A.T.O. Alliance to the ex-Soviet countries directly threatens Russian regional power as well as internal security. U.S.A. strategy aims to keep Russia far from European continent and Mediterranean Sea, building up a containing chain of hostile countries, all long Russian boundaries [2].

As well known, Ukrainian putsch was part of this strategy: the role of U.S.A. politics and lenders in so-called "Euromaidan" protests aimed to bring out, from Russian sphere of influence, a key country for the control of Black Sea. Just after Yanukovych departure from Kiev, in February 2014, when he was forced to flee from Ukraine, N.A.T.O. launched a big military operation in Eastern Europe.

In March 2014, in the middle of the Ukrainian change of government, N.A.T.O. launched the "Operation Atlantic Resolve", a big effort involving Dutch, German, Belgian and U.K. troops in Ukraine (headed by temporary government), Baltic countries, Poland, Bulgaria and Romania.

Russian response was immediate: after a regional referendum, in March 2014 Russia annexed Crimea, where is the most important naval base of Russian fleet in Black Sea. In April 2014, Russian backed activists stormed SBU (Security Service of Ukraine) offices in Donbas and Luhansk, Russian-speaking majority regions in Ukraine, and declared establishment of D.P.R. (Donetsk People's Republic), L.P.R. (Luhansk People's Republic).

Since then, Ukraine's civil war became the military outlet of a global tension between Russia and U.S.A., a competition very similar to Cold War. Unfortunately, atomic deterrence seems now unable to prevent an armed war on wide scale. In facts, during the Cold War, the N.A.T.O. troops never clashed directly against Russian army. On the contrary, in this case, clashes are going to involve directly Russian army against N.A.T.O. armies, with an important presence of U.S.A. troops on the ground. The Turkey's downing of a Russian plane in Syria, is just the consequence of a long 
period of tension between N.A.T.O. and Russian army, which has set mainly on the European-Russian border and in Baltic region.

During 2015, the "Operation Atlantic Resolve" grew faster, involving a rising amount of troops and equipment in Europe [3]. On the other side, Russia reacts by supporting D.P.R. and L.P.R. militants, and by growing military presence in Belarus, Kyrgyzstan, Tajikistan and Armenia.

By accepting the separation and the Russian annexation of Donbas, U.S.A. would betray security request of ex-Soviet States scared for Russian aggression. On the other hand, Russian withdrawal from Crimea and Donbas would destabilize Belarus, Kazakhstan and Georgia; even Putin's power would be shaken in Kremlin. These elements are going to radicalize clashes, and to make situation difficult to solve.

\section{Energy Issue and Gas War}

On background of the Ukrainian crisis, there is the problem of energetic supply of Europe. Parallel to the armed war, in fact, Ukraine is the battleground of a gas war involving economic development and energetic security of Europe. With gas war, we mean the competition between Russia and U.S.A. in European natural gas supply.

From the falling of Soviet Union, Russia founded its economic growth on hydrocarbons export, and used this element as a strong pressure tool for foreign politics and geopolitics influence. Russia built a dense network of pipeline for oil and gas in Europe: one third of energetic European supply depends from this network. This dependence is the Russian tool to control European states and, in particular, ex-Soviet states: Moscow applies a rate policy to these countries according to level of relationship amongst governments.

Recently, U.S.A. decided to work to recover this strategic vantage, by proposing itself as alternative exporter of natural gas and oil, with the aim of broking Russian monopoly, particularly in European supply. With this aim, U.S.A. started the so-called "shale revolution": with an incentive and investment policy, Washington reached high level in hydrocarbons production with the shale method, becoming in 2014 the first producing country in the world, overcoming Saudi Arabia and Russia.

Meanwhile, due to economical global crisis, and due to lower growth level of China, petrol global request decreased, and oil price fallen down. Some oil exporter countries asked for a global reduction in oil production in order to keep prices at survival level: but O.P.E.C. (Organization of the Petroleum Exporting Countries), headed by Saudi Arabia, decided in 2014 and 2015 to keep production at the same level of the time before crisis. The O.P.E.C. decision is geopolitical. In facts, with an oil barrel price lower than $60 \$$, expensive shale mining investments of U.S.A. become out of market.

Obviously, the O.P.E.C. decision also damages Russia.
Moscow is lying in economic difficult due to oil price and Western sanctions: national economy stopped to grown and is now close to recession. During 2014, the Russian GDP has grown to $0,6 \%$ against $3,4 \%$ of 2012 and $4,3 \%$ of 2011 [4]. But, due to low ruble, gas export is still competitive, and Russia - thanks to a public industrial gas system and existing extractive facilities - doesn't need important investments for oil and gas, like U.S. does. In December 2015, OPEC refused again to reduce production, bringing a new price fall for crude oil, traded under $40 \$$ a barrel [5].

\section{Ukraine: Crisis of a Key Role Country}

Ukraine is a key hub for Russian gas delivery to Europe. Through this big territory, pass main pipelines bringing gas to European Union, fundamental marketplace for Russian economy [6]. Strategic centrality of Ukraine for gas transportation became evident during winter between 2008/2009 when, due to the price issue, Russia halted gas supply to Ukraine, harming many European countries [7]. Since that winter, European Union authorities started to look for alternative ways of energetic supply, in order to tear loose from Russian dependence: in facts, $30 \%$ of gas used in Europe comes from Russia, and $40 \%$ of this gas passes through Ukraine. In the same time, Russia started to work in order to strengthen bilateral relationship aiming to build alternative pipelines to Europe bypassing Ukraine.

Not only Europe needs Russian gas, but also Russia needs European marketplace: a big share of Gazprom export go in Europe. In 2013, 82,3 bcm of gas passed through Ukraine, out of $167,2 \mathrm{bcm}$ in total exported in Europe. Furthermore, gas flow for Europe is growing faster despite crisis: imports grew from $144,5 \mathrm{bcm}$, due to political and security crisis in North Africa and Middle East [8].

So, while Russia is trying to bypass Ukrainian hub for European flow, in order to better control internal politics, Europe is trying to find alternative ways for supply to free Ukraine from economic and political dependence.

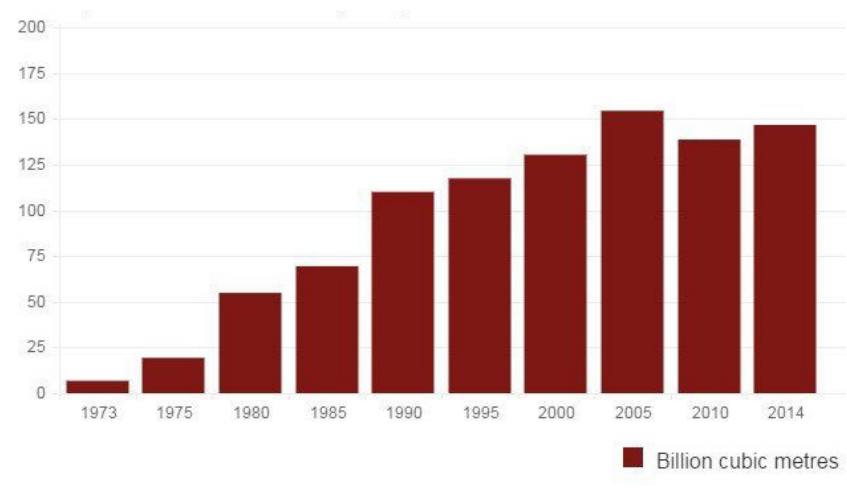

Source: Gazprom

Figure 1. Gazprom gas exports to Europe. Europe is the main marketplace for Russian natural gas. 


\subsection{Ukrainian Crisis}

Meanwhile, Ukraine lays in a serious economic crisis and is really close to default. In 2015 August, Fitch rated Ukrainian debt "C", which means "Exceptionally high levels of credit risk. Default is imminent or inevitable, or the issuer is in standstill" [9]. The debt is growing also due to high energetic dependence of the country: while Ukraine's energetic production rest really low, natural gas consumption is one of the highest in European continent ( $4^{\circ}$ rank in Europe, just after UK, Germany and Italy).

In facts, after political crisis, domestic production of energy decreased significantly for two main reasons:

- Political reason. Ukrainian energetic field is fully handled by pro-Russians oligarchs, appointed by Yanukovych, and they fully control domestic mining: Poroshenko increased domestic mining taxes in order to weaken their power. Because of this, main foreign companies, like Chevron, left the country. In addition, nuclear sector, with its soviet plants, still depends on Russian uranium.

- Geopolitical reason. Main gas production is in Crimea offshore fields, annexed from Russia. In the same way, the Ukrainian project for reorganization of energetic production, based on coal mining, is made vain due to civil war in Donbas and Luhansk, where are the main coal mines: just 24 out of 93 mines are now under Kiev control, while 69 remaining are under control of Donetsk People's Republic and Lugansk People's Republic.

Ukraine tried to solve the problem by purchasing coal from South Africa, but seller Steel Mont Trading Ltd., committed to send 1 million tons of coal, pulled out of contract to avoid involvement in country's domestic situation [10]. So, Ukrainian energetic domestic system is still tied to gas supply from Gazprom, which halted supply many times from the start of the war, due to difficult to find an agreement on the price.

Taking advantage from this situation, Gazprom is pressing Ukraine to remain tied to Russian company, with which signs price agreements every six months. Recently, in November 2015, Russia halted again the gas supply, due to Ukrainian refuse to pay gas supply to occupied territories of East [11].

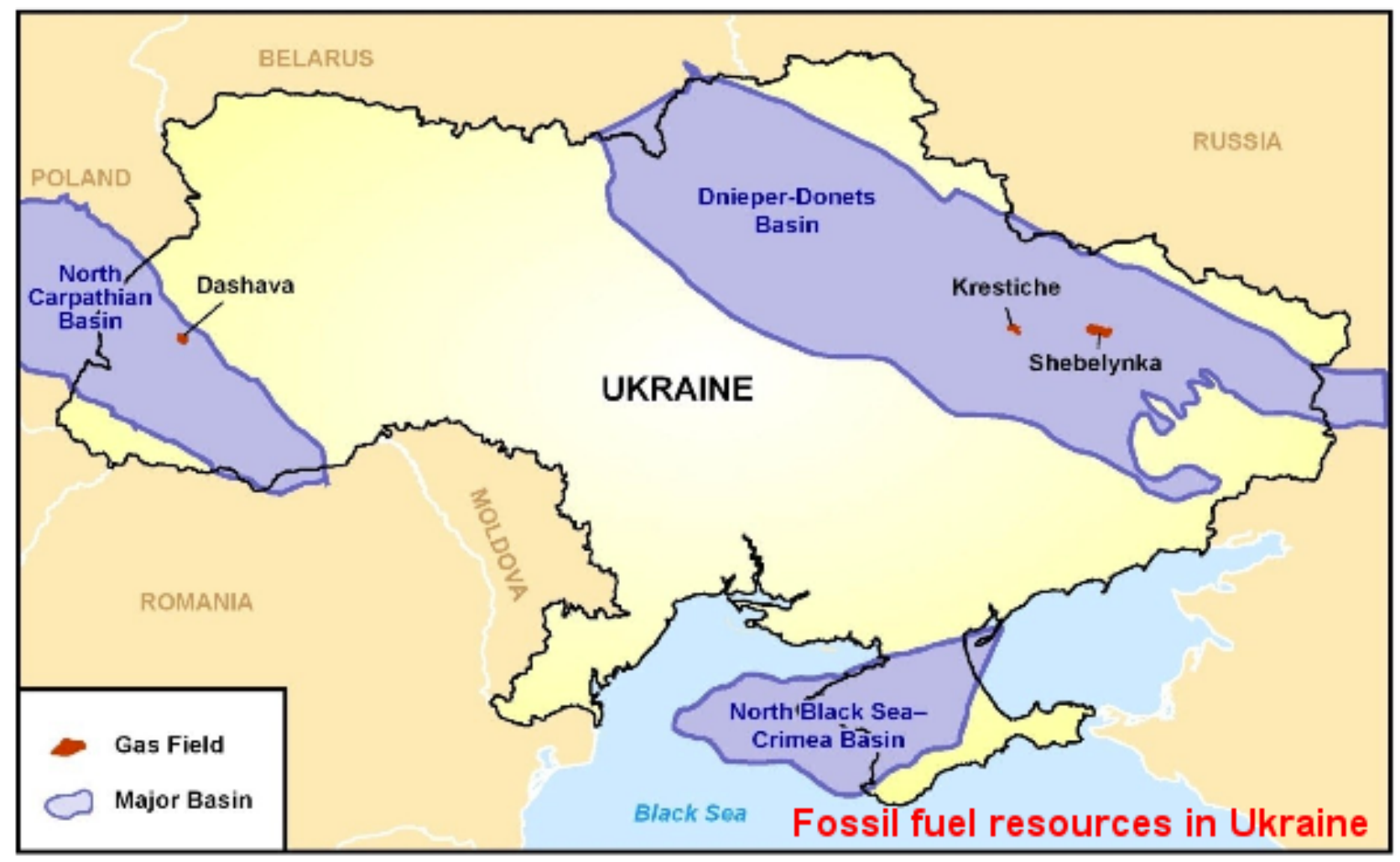

Source: IHS CERA

Picture 1. Fossil fuel resources in Ukraine. In the map we can see how civil war and Crimea annexation affect Ukrainian fossil fuel mining. 


\section{New Russian Projects for Selling Gas}

Moscow is trying to overcome Ukrainian bottleneck by opening new routes for Europe, with different pipelines and LNG projects. LNG is an important innovation for Russian energy market: in the Russian plans, due to global warming ships will be able to move from Siberia during the whole year, without pipelines and without icebreaker ships, allowing Russia to reach far marketplaces without costs related to lack of pipeline.

Main project is the Yamal LNG plant: Russian government is quickly building it, with a planned expense of 150 billion dollars. Second LNG plant is to be built in Baltic Sea, in the Ust-Luga port, close to Estonia boundary. Thanks to this plant, Russia aims to start competition with Norwegian LNG supply to Baltic countries, and to prevent coming of U.S. LNG, expected for 2016.

State-controlled company Gazprom is also working to open new routes for South America. However, the main target for Gazprom is Asiatic marketplace: Russia reached an agreement with China for selling gas through "Power of Siberia" pipeline and through LNG route from Yamal. In 2015, Putin went to Beijing in order to reach a second supply agreement through "Power of Siberia 2" pipeline that would turn China in the main customer of Gazprom.

Besides LNG plants, Gazprom is planning building new pipelines to reach Europe, trying to bypass Ukraine. Main projects aim to reach central Europe through two different routes: southern and northern. From the southern side, after abandoning South Stream project due to EU opposition, Russian company is now working on Turkish Stream, a pipeline through Turkey, Greece and perhaps Balkan, aiming to compete with official European project TAP-TANAP: in facts, gas field for this pipeline can't guarantee long time supplies, unless involvement of Iran. Turkish Stream project was in advanced stage of projecting, when Turkey F-16 fighters downed a Russian Su-24 frontline bomber, in 24 November 2015. In retaliation, Moscow government decided to freeze some investment project with Turkey, including Turkish Stream.

On the northern side, Gazprom is trying to draft a pipeline connection with central Europe. First project was "Yamal-Europe 2", a link between Poland, Slovakia and Hungary. However, the project was abandoned after Polish firm rejection. The second project proposal was luckier: it plans to double capacity of existing Nord Stream Pipeline, a working pipe linking Russia and Germany through Baltic Sea.

\section{European Countries and the Lack of Common Strategy}

\subsection{One Europe, Too Much Strategy}

The leading actor in the gas war should be European
Union. In facts, the gas dependence on Russian is a big problem for Europe, unable to draft an independent development program due to energy security issue [12]. In addition, the casus belli in Ukrainian putsch was Yanukovych's attempt to block integration process with European Union: "Euromaidan" protester fought in order to join European Union, and this should be a political issue for Brussels agenda. On the contrary, European Union still lays in a substantial lack of common policy in energetic issue.

The European way to help Ukraine in gas supply is the reverse flow: Russian gas is reverse flowed through pipeline from Hungary and Slovak. In this way, Slovak (and in a lower level Hungary), with the strong opposition of Gazprom, supplied Ukraine with Russian gas, granting lesser prices: reverse flow was possible because Gazprom is selling gas to these countries at lower price than Ukraine. Thanks to reverse flow, in July $2015 \mathrm{Kiev}$ get to settle temporary halting of gas purchase, taking revenge for Russian blackmail power, and trying to reach lower rates. When reverse flow is not enough for domestic needs, Kiev use to consume gas stored in strategic reserves: according to Gas Infrastructure Europe, in 2015 February just 28,58\% was left in strategic Ukrainian reserves [13]. Russia tried to react against reverse flow by reducing gas flow to Slovak: this reduction caused a price increasing of reverse flow gas, which became more expensive for Ukraine than Russian flow.

Besides reverse flow policy, in 2015 EU launched European Energetic Union. The project was proposed by Poland, expecting to build a unique body for European energetic supply, and met the favour of Ukraine and ex-soviet countries, wishful to free from historic dependence from Russia. European Commission designated as president Slovak Maroš Šefčovič, vice-president of European Commission, and he defined main strategic targets:

- $\quad$ Supply security;

- A fully-integrated internal energy market;

- Energy efficiency;

- Emissions reduction and research and innovation.

Šefčovič started an "Energy Union Tour" in order to persuade European countries about the development chances related to a common strategy. Despite these efforts, Energetic Union struggling to become real, and still risks to fail due to lack of common politics: on energy issue, European countries are still divided in single national strategies.

The main division concerns the choice of a common strategy: while many countries would increase domestic production, also by implementing polluting techniques like coal and shale gas and oil, other ones are strongly opposing these ways, due to environmental reasons.

Also in relationship with Russia, EU countries are running own strategy on energetic supply, despite necessity of a common vision. We can summarize them in two groups: Anti-Russian and "lone wolves" countries. The countries were collected according to the national policy announced 
in the field energetic supply. Within the Anti-Russian group are collected the countries that are improving their policy in order to reach independence from Russian supply, some of which are working in order to allow U.S.A. shale gas to entry in Europe. In the "lone wolves" group are collected the countries that are following their own policy, strengthening their ties with Russia despite Western sanction and European independence strategy. While a complete overview of both groups can be found in picture 3 , in the following paragraph some of these countries are listed as an example. Particularly, the countries mentioned are those which announced, in the last months, new political decisions aiming to weakening or strengthening ties with Russia.

\subsection{Anti-Russian Countries}

The anti-Russian countries group is mainly composed by some ex-Soviet countries, hardly pushing for a European energetic independence from Russia due to cultural reasons: in facts, after falling of Soviet Union, these countries strengthened ties with Europe (and with N.A.T.O.) in order to free from Russian influence.

In this group, we can find Romania: from the beginning of South Stream saga, Bucharest opposed project in solidarity with Ukraine, and started to look for new autonomous energetic sources. Main Romanian project is the "AGRI": Azerbaijan-Georgia-Romania LNG Interconnector, that is part of European strategy but let Romania a central role [14].

Also, the Baltic States are still fully depending on Russian gas. Distrusting Europe, they started building a LNG plant in Lithuania, in order to supply Baltics states with Norway gas (virtually they can reach $90 \%$ of needed), while Finland is planning to build a LNG plant in Pori with an expenditure of 23 million euros. The problem is that Norwegian gas is more expensive compared to Russian gas and this difference is growing up due to devaluation of ruble: for this reason, Russia started building LNG Baltic plant, in order to keep gas competitiveness in the region. In Adriatic Sea, Croatia is trying to become the LNG hub for southern Europe. These countries also aim to buy U.S. LNG, and some of them signed agreements for this.

Countries without seashore, as Czech Republic, unable to build LNG plants, are following path of nuclear plants development as a strategy to limit dependency on Russia. Also Bulgaria is discussing about nuclear way to energy, after scupper South Stream Russian plan.

As well known, Sweden and Poland has difficult relations with Moscow due to some many political issues: within energetic issue, Sweden is in the potential right to block Nord Stream 2 project by interdicting transition of pipeline in its exclusive economic sea zone. On the other hand, Poland is planning a national energetic security strategy: in November 2015, Prime Minister Beata Szydlo announced an energetic plan composed by coal production,
LNG importation and oil supply diversification. Until now, $90 \%$ of Polish oil import (23,6 million tons) and $60 \%$ of gas import comes from Russia. In the future, Poland will be able to differentiate hydrocarbon imports. However, the national strategy is still founded on coal mining: to keep coal as a pillar of energy strategy, Warsaw is going to oppose EU pollution rules [15].

\section{3. "Lone Wolves"}

The "Lone wolves" group is composed by all the countries working to strengthen ties with Russia, despite Western sanction and EU strategy, which expects European countries to reduce dependency from Moscow. Some of these countries are not looking for a special relationship with Russia, but they are working to find national strategy for energetic supply, in direct contradiction with EU instructions.

Hungary and Greece are the European countries more committed in working for a European or national agreement with Moscow, despite EU and U.S.A. attempts to avoid it. For different reasons, these countries represent a real thorn in the side of EU, because their policies are closely related to Russian interests in European space.

Russia is one of the main political partners of Greece: during the Greek government debt crisis in spring 2015, Athens get closer to Russia by joining Turkish Stream project and letting Russian warships to stay in territorial waters. While Brussels was asking for austerity, Russia offered investments.

Friendship between Russia and Greece became stronger after Turkey's downing of Russian aircraft. According to military sources, Turkish planes used to violate Greek airspace 2244 times in 2014, and 1443 times in 2015 (January-October data) in the context of historic bad relationship between Athens and Ankara [16]. The accident between Russia and Turkey brought a closer tie between Athens and Moscow.

The second Russian-friendly country is definitely Hungary, leaded by Orban, one of the best European friends of Moscow. In 2014, after strong protests by Gazprom, Hungary halted reverse flow to Ukraine, giving technical reasons. In February 2015 Putin visited Budapest, where signed an agreement to build two nuclear plants for Hungarian energetic strategy. Hungarian premier Orban also offered Gazprom to use underground stored for Russian gas.

Some other European countries are following national strategy in energetic supply, despite Šefčovič efforts. One of these is Slovak: despite an anti-Russian public opinion, Bratislava refused from the beginning to join NATO anti-Russian operation "Atlantic Resolve" but, at the same time, was the main country involved in reverse flow to Ukraine, despite hard opposition of Gazprom.

Slovak is now heading European Energetic Union, but keep also close tied to Russia in bank field and energy field 
and try to find a national strategy in energy security, swinging between EU loyalty and keeping relationship with Russia. The main reason for this politics is that Slovak is the second key transit country for Russian gas to Europe. Thanks to reverse flow, Slovak aspires to become the new transit hub for Russian gas in both ways.

Another country following own strategy in Russian relations is Italy: ENI, the state-controlled company in energy field, was one of the main supporter and shareholder of South Stream project from the beginning. SAIPEM, an Italian oil and gas industry contractor, was building pipeline in the offshore part in Black Sea, when Gazprom halted project. On the other side, Italy became the last step of EU TAP-Trans Adriatic Pipeline project, bypassing Russia, and joined Western sanctions against Moscow. Furthermore, Italy rest closely tied to Gazprom and industrial system of Russia. In August 2015, ENI discovered a supergiant gas field in Zohr Prospect, in Egyptian offshore: the largest gas discovery in Mediterranean sea, with a potential production of 5,5 billion barrel of oil on a 100 square kilometres surface. This discovery would increase independency rate of Italy from Russia and from European strategies on gas supply.

In Balkan Peninsula, Slovenia is strengthening ties with Russia, aiming to be selected as European terminal of the foreseen South Corridor, but the probably unexpected country in this group is Germany. In summer 2015, when Greek premier Tsipras met Putin in order to sign agreement for Turkish Stream, many German politics charged Greece for betrayal of European unity spirit. However, while European Union tried to maintain centrality key role of Ukraine in gas supply, Germany decided to sign an important agreement with Russia for the doubling of Nord Stream. The announcement was given as long as Ukraine was trying to reach a sustainable agreement for the gas price from Gazprom.

The Germany decision shocked and angered Baltic and ex-Soviet countries, denouncing the "Molotov-Ribbentrop Pipeline": in this way, in facts, Russia will sell gas to Europe through pipeline, fully bypassing Ukraine and rising Germany to a key role in gas transit. EU is now checking eventual legal actions against Germany act, considered in contradiction with European strategy for energetic independence. In November 2015, ten European countries (Poland, Czech Republic, Slovakia, Hungary, Romania, Greece, Estonia, Latvia, and Lithuania) signed a letter asking for a summit-level EU debate on Nord Stream 2 Project. Germany can count on support of Austria, Denmark and France. The latter, in particular, highly increased import of Russia’s natural gas.

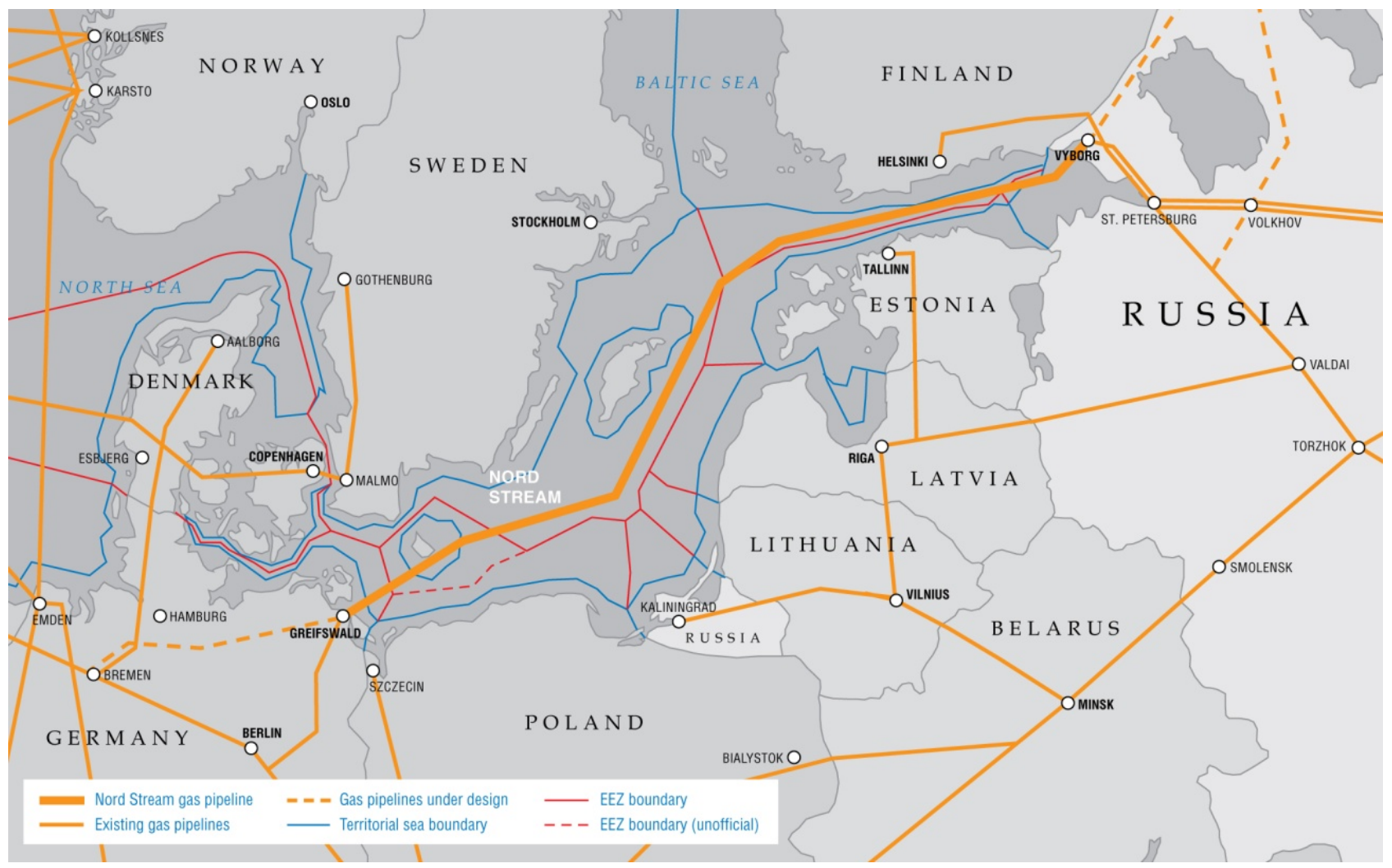

Source: Gazprom

Picture 2. Nord Stream and pipeline network in Baltic Sea. 


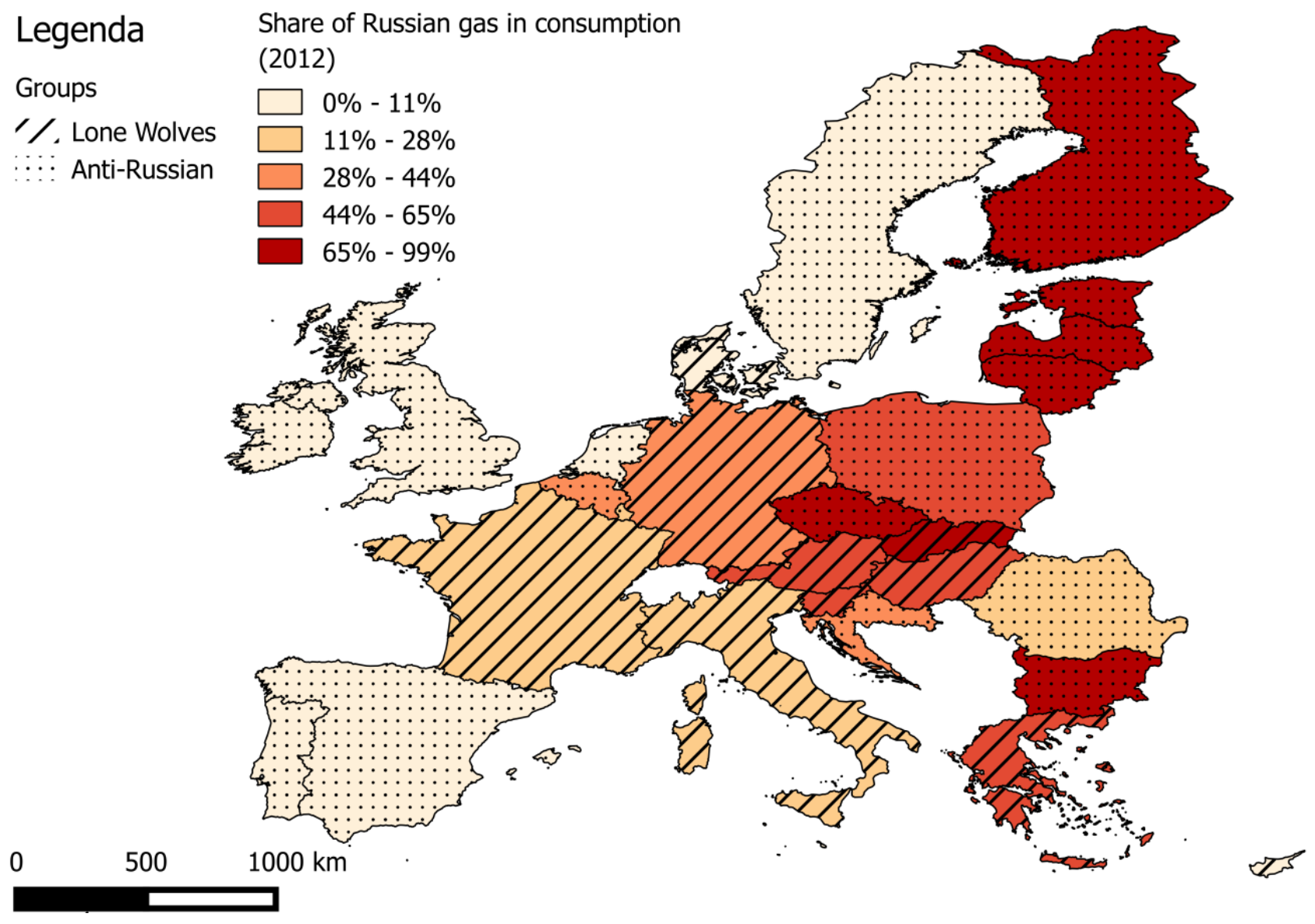

Source: Author processing on Gazprom and BP Statistical Review 2013 data.

Picture 3. Anti-Russian and "Lone wolves" groups and share of Russian gas in consumption.

\section{Conclusions}

In November 2015, during a meeting on the development of the Russian Armed Forces, President Putin announced the project for an anti-missile defence system, and another project of a strike system capable to penetrating anti-missile defence shield (referring to U.S. defence European program officially planned to prevent alleged attacks from Iran and North Korea). During the meeting, a Russian state-owned television leaked a secret document showing Russian nuclear military defence plans against West [17]. The accident - probably planned from Russian officials with the purpose of sending a message to N.A.T.O. Alliance maintaining around 5000 troops in Baltic countries - shows how the high tension could be easy turn in a new Cold War, or in a hot one.

In this scenario, wherein tension is growing faster, Ukrainian gas war is going to jeopardize European unification process: while Europe lay in the lack of common politics, every country follows a national strategy trying to achieve better result despite European efforts to reach energetic independence. Without a real European common energetic supply strategy, U.S.A. and Russia are going to come back in European control, using natural gas issue as a geopolitical tool: in a new way, after 17 years from the fall of Berlin's wall, Europe is again shared in opposed blocks.

\section{REFERENCES}

[1] A.N. Stulberg. Out of Gas? Russia, Ukraine, Europe and the Changing Geopolitics of Natural Gas, Routledge, Problems of Post-Communism, Vol. 62, No. 2, 112-130.

[2] R. Pradhan. Russo-American Engagement in Ukraine: Geopolitics at work, IUP Journal of International Relations, Vol. 9, No. 1, 7-20.

[3] J. Granger. Operation Atlantic Resolve. A Case Study in Effective Communication Strategy, Military Review, Online available from http://www.U.S.A.cac.army.mil

[4] http://www.worldbank.org/

[5] H. Tan. Oil under $\$ 40$ barrel on OPEC production, could hit $\$ 20$ s in 2016, Online available from http://www.cnbc.com/

[6] Keith. C. S. Security Implications of Russian Energy Policies, CEPS Policy Briefs, Issue 1-12, 1-5, 2006. 
[7] S. Pirani, J. Stern, K. Yafimava. The Russo-Ukrainian gas dispute of January 2009: a comprehensive assessment, Oxford Institute for Energy Studies, Oxford, 2009.

[8] M. Assenova, Russia-Ukraine War's Impact on European Energy-A Net Assessment of Developments in Europe's Energy Security Strategy Since the Start of 2014, Eurasia Daily Monitor, Vol. 11, No. 185.

[9] http://www.fitchratings.com

[10] A. Vitelli. Steel Mont Cancels Ukraine Coal Supply Contract, Bloomberg Business, Online available from http://www.bloomberg.com/

[11] J.C.K. Daly. War in Eastern Ukraine Causing Coal Shortages, Electrical Blackouts, Eurasia Daily Monitor, Vol. 12, No. 12.

[12] D. Klimczak. Influence of Ukrainian crisis on the European gas market, Energy \& Environment, Vol. 26, No. 3, 425-435.

[13] http://www.gie.eu

[14] P. Belkin, J. Nichol, S. Woehrel. Europe's Energy Security: Options and Challenges to Natural Gas Supply Diversification, CRS Report for Congress, Online available from http://www.crs.gov

[15] M. Strzelecki, M. Martewicz. How Poland's CrU.S.A.de for Energy Autonomy Affects EU and Russia, Bloomberg Business, Online available from http://www.bloomberg.com/

[16] N. McCarthy, Turkish Jets Violated Greek Airspace Over 2,000 Times Last Year, Forbes, Online available from http://www.forbes.com

[17] Tikhonova P. Russia Announces Nuclear Arms Race with U.S., Online available from http://www.valuewalk.com 